\title{
1. Foundations of the international drug control regime: nineteenth century to the Second World War
}

\author{
William B. McAllister ${ }^{1}$
}

\section{INTRODUCTION}

This chapter outlines the principal factors contributing to national governments' negotiation of globally applicable rules that defined the boundaries of the licit drug trade. A centuries-old, increasingly robust, unregulated traffic in opium across Asia proved so problematic by the early twentieth century that states deemed it necessary to act. In forging a series of international treaties, governments protected domestic priorities, ensured low prices for medicinal substances, and focused on limiting the supply of the key agricultural raw materials: opium and coca. States sanctioned the creation of international regulatory bodies to track the licit trade and enforce the rules. In certain respects, the regime proved successful, but the treaties also created incentives for entrepreneurial smugglers that fostered a permanent illicit traffic. In the first half of the twentieth century, states determined the basic pitch of the playing field; the fundamental thrust of those rules, institutions, and practices remain intact today.

Today's global "drug problem" is inextricably intertwined with the international regulatory system intended to address the issue. This co-dependent relationship evolved over the last three centuries as an unprecedented array of forces interacted on the world stage. Over the first half of the twentieth century, those factors combined to generate a formal set of arrangements designed to limit humans' access to powerful psychoactive substances. The rules and structures created by drug control advocates 100 years ago illuminate the perennial dilemmas inherent in the "drug question" (McAllister, 2000).

\section{NINETEENTH CENTURY TO 1909: GRADUAL DEMISE OF TRANSNATIONAL LAISSEZ-FAIRE}

Psychoactive substances, and the regulation thereof, have always played an important part in human civilization. For example, societies across the planet produced alcoholic beverages wherever feasible, but also routinely discouraged indiscriminate use. As intercontinental exchange increased during the fifteenth through seventeenth centuries, traders disseminated substances indigenous to one region around the globe. Consumers developed cravings for New World tobacco, African coffee, Asian tea, and South American chocolate. Technological innovations in the late nineteenth century enabled synthetization of Andean coca into cocaine,

1 The views expressed in this chapter are the author's and do not necessarily represent those of the US government or the Department of State. 
which launched that drug on to the global scene. Local communities, government officials, religious authorities, social reformers, and other gatekeepers frequently attempted to limit access to such substances (especially alcohol) because of the manifest negative effects of misuse.

A burgeoning worldwide traffic in opium that arose in the eighteenth century propelled states toward international measures to control a select subset of the larger array of psychoactive substances. Consumers in China and the European powers' East Asian colonial territories developed a propensity for smoking opium; Dutch, British, and Portuguese entrepreneurs responded by producing and exporting increasingly large amounts of the drug. Colonial governments raised tax revenue through opium "farming" (e.g. selling exclusive opium retail distribution contracts to concessionaires who maximized sales to turn a profit). In part to redress a persistent trade imbalance, Europeans expanded shipments to China as well, despite imperial edicts promulgated in the 1790s that banned opium imports. In the nineteenth century, European powers utilized war and coercive trade agreements to force unfettered access to the Chinese market, which stimulated the flow of opium into the region. The Chinese government eventually rescinded its opium ban in order to raise tax revenue from the commerce, which enabled domestic cultivators to enter the business. That combination of factors flooded the market to an extent unsurpassed in human history. ${ }^{2}$ By the turn of the twentieth century, many observers feared that the opium problem would contribute to the collapse of the Chinese state.

Instability in the Middle Kingdom, fuelled in large measure by widespread opium consumption, threw the issue into the realm of geopolitics. Several influential European states, most notably the governments of Germany, France, and Russia, perceived advantages in dividing China into spheres of influence similar to the "Scramble for Africa" that began in 1885 .

2 The 2017 International Narcotics Control Board Annual Report, p. 25, stated that stocks of "Opiate Raw Materials" (ORM) rich in morphine and ORM rich in thebaine (both consisting of poppy straw, concentrate of poppy straw, and opium) sufficient to meet licit needs totalled around 800 metric tons, https:/ www.incb.org/documents/Publications/AnnualReports/AR2017/Annual_Report_chapters/Chapter_2 2017.pdf (accessed: 6 April 2019). Given a 2017 world population of about 7.7 billion, current world licit need works out to a supply of roughly one metric ton of ORM per 9.625 million people. Although even rough estimates defy confirmation, sources from around the turn of the twentieth century indicate that opiate consumption in China and the European powers' East/Southeast Asian colonies probably amounted to at least 20,000 metric tons per year (consisting primarily of opium prepared for smoking but also increasing amounts of heroin and morphine; that figure includes recorded legal exports/imports plus a very conservative estimate for massive smuggling operations as well as the considerable amounts traded by colonial authorities on their private accounts). To account for differences in morphine content between prepared (i.e. smoking) opium and the modern standard ORM measure, I consulted with INCB technical experts and concluded that the conversion ratio from 1900 to today is approximately 4:1. That is to say, 4 metric tons of smoking opium in 1900 yielded approximately the same amount of morphine base as 1 metric ton of today's ORM. Given a global population of about 1.6 billion in 1900, that amounts to a supply of approximately 1 metric ton of opiate raw materials per 320,000 people. In sum, per capita world opium supplies in 1900 totalled roughly 30 times as much as is necessary for today's licit medicinal purposes. Adding into account current-day illicit production of approximately 2000 tons yields a figure of 1 ton of ORM equivalent per 2.75 million people, about 8.5 as much opium per capita when compared with 1900. In sum, it seems highly likely that, on a global per-capita basis, the late nineteenth-century supply of morphinic substances has never been exceeded. For a general overview covering the seventeenth-early twentieth centuries, which relies upon published primary sources for production figures, see Derks, H. (2012) History of the Opium Problem: The Assault on the East, ca. 1600-1950. Leiden: Brill. 
Officials of the strongest colonial power, the UK, calculated that maintaining intact Chinese territorial and governmental integrity benefitted their interests because the UK was best positioned to exert influence and sell goods across the entire country. Leaders of the US, the colonial power least able to project power on the Asian mainland, arrived at the same conclusion: an "open door" throughout China reduced entry costs to promote commerce and enabled Washington to exercise leverage. The UK and US took the lead in advocating international control agreements. Drug policy, therefore, became entwined with the "Great Game" between the Great Powers that played out across Asia in the decades around 1900.

Public health advocates and social reform activists in countries at the forefront of the later-nineteenth-century Second Industrial Revolution (Europe, the US, the predominantly white settler colonies of Canada, Australia, and New Zealand, and to some extent Japan) also contributed to the international control impetus. Pharmaceutical firms - among the original transnational corporations - developed and marketed new substances with little oversight. Problems associated with patent medicines generated societal demands to reveal the contents and ensure the quality of all drugs. Many feared that a new cohort of younger, socially marginal users who took drugs purely for pleasure threatened societal cohesion. Physicians possessing professional knowledge advocated for control over prescribing medicines. Pharmacists claiming specialist expertise argued for exclusive rights to retail distribution of a steadily increasing array of substances. With increasing support from their constituents, authorities at the local, provincial, and national levels imposed a variety of access-limitation measures and drug-purity regulations intended to protect the populace. It soon became apparent, however, that disparities between national jurisdictions invited exploitation by profiteers. Without a common approach to control, governments inevitably faced illicit trafficking in high-value, low-bulk commodities well suited to smugglers attracted by favourable reward-to-risk calculations.

Increasing moral sensibilities, especially among those supporting Christian missionary activities, spurred European governments with Asian possessions to reform colonial opium policies. Several powers replaced "opium farm" concessionaire arrangements with colonial government monopoly distribution schemes intended to remove the profit incentive; salaried colonial officials sold opium only to individuals listed in registers restricted to current users. Ostensibly, the user base would die out over time, causing the opium problem to vanish. Colonial governments, however, became addicted to the revenue derived from monopoly sales, and the registers remained open to new users. Moreover, illicit purveyors circumvented official monopoly systems by trafficking across colonial boundaries at attractive prices. The problems associated with government opium monopolies also contributed to the impetus toward international cooperation; reformers aimed to forge a common set of rules to curb excessive trading in opium.

A unique bilateral mutual self-limitation contract inaugurated the era of international drug control agreements, generating a "lessons-learned" legacy that impacted regulatory advocates' assumptions for the remainder of the century. In September 1906 the Imperial Chinese government promulgated an edict to suppress domestic opium cultivation over the ensuing decade. His Majesty's Government responded by negotiating to curb Indian opium exports to China. The resultant "Ten Year Agreement" went into effect 1 January 1908. It stipulated that by 1918 China would eliminate all cultivation and the UK would terminate shipments from India. In a sign of the power disparity between the two parties, London secured an exceptional privilege: Beijing conceded to British officials the right to conduct inspections on Chinese territory to ensure compliance. During its first three years the initiative appeared on the way 
to success; British inspections confirmed substantial reductions in Chinese cultivation, and Indian exports dropped precipitously. In late 1911, however, the Qing Dynasty collapsed amid revolution. China fell into a protracted period of governmental dysfunction and political disunion. Warring factions facilitated domestic opium cultivation and sales to obtain revenue that supported military and governmental operations. Nevertheless, opprobrium against the international trade proved so pronounced that UK officials ended legal Indian opium shipments to China in 1913. Control advocates concluded that this episode demonstrated the fundamental soundness of a supply-control approach to the problem: it appeared the issue would have been resolved had the Chinese state maintained the governmental capacity and political will to finish the job. Most observers came to believe that the recipe for success consisted of strictly limiting supplies to legitimate medical and scientific needs by monitoring cultivation, pharmaceutical production, and distribution. Governments compliant with international expectations could promote that goal by pressuring recalcitrant states to conform. Those assumptions suffused the subsequent construction of the global drug control regime, and remain a powerful influence today.

\section{9-1924: INTRODUCING HORTATORY NORMS}

Around the time the bilateral Ten Year Agreement went into effect, the US government emerged as the leading advocate for a multinational approach to drug regulation. US foreign policy objectives coincided with the interests of a coalition of religious, moral reform, and medical leaders who advocated pan-Asian control measures. The Department of State launched a diplomatic campaign to persuade reluctant colonial powers to consider the issue at an international meeting. The principal parties eventually acquiesced, but only to send delegates in an advisory capacity; governments proved unwilling to designate plenipotentiaries empowered to negotiate a binding agreement. The resultant International Opium Commission met in February 1909 at the Chinese port city of Shanghai. ${ }^{3}$

The Shanghai talks highlighted fundamental points of disagreement that dogged drug negotiations throughout the twentieth century. The US favoured a minimalist definition of "legitimate" use restricted to medical and scientific purposes, as determined by criteria utilized in the industrialized west. That approach, however, failed to recognize that many societies could neither access nor afford modern drugs; "traditional medicine" remained the norm for much of the planet. Those accused of purveying excess raw opium attempted to expand the scope of the problem by claiming that newer manufactured drugs such as heroin and morphine had proven at least as addicting. Including pharmaceutical substances in the discussion threatened the interests of leading industrial states such as Germany, France, and the Netherlands. Recalcitrant governments raised the universality issue: if some states agreed to forgo cultivation, manufacture, or trade, others would simply take over and reap the profits. Few believed it possible to engineer a level playing field in which the rules applied equally to all; it therefore served no purpose to voluntarily disadvantage one's own nationals. The delegates produced an array of non-binding, generalized recommendations that governments could interpret as they wished (INCB, 1959). Nevertheless, international control advocates gained momentum

3 Delegates attended from Austria-Hungary, China, France, Germany, Italy, Japan, the Netherlands, Persia, Portugal, Russia, Siam (Thailand), the UK, and the US. 
because they seized the moral high ground; although not agreeing on the particulars, states acknowledged that a transnational drug problem existed and that they had a responsibility to address the issue.

US officials soon called for plenipotentiary negotiations to produce a treaty obligating governments to act. They proposed a package of stringent regulations including controls over opium production, manufacture, and exports, overall limits on opium cultivation worldwide, uniform national control and penal laws, amassing and sharing statistics on all aspects of the trade to track diversions, and even reciprocal rights to board ships suspected of trafficking on the high seas. US actors encouraged control advocacy constituencies in other countries to pressure their governments. Twelve states agreed to attend, ${ }^{4}$ but many insisted on agenda amendments to protect their special interests. London wanted controls placed on pharmaceutical opiates including heroin, morphine, and codeine, which elicited significant protest from Berlin. Rome insisted on including hashish/marijuana, which most observers viewed a minor problem that distracted delegates from the central issue of opium and its derivatives. Paris refused to amend domestic legislation. Tehran, St. Petersburg, and the British colonial Indian government objected to interference with their right to produce opium for domestic consumption, which they considered an internal affair. Lisbon insisted it would only comply with the prospective treaty's provisions if all other governments-including those not invited to the conference-also adhered. The Ottoman Empire (a major opium growing state) and Switzerland (a principal pharmaceutical manufacturing state) declined to attend, which imperilled universal application of the treaty's provisions. The parties met from December 1911 to January 1912 at The Hague in the Netherlands to negotiate the International Opium Convention.

The conflicting interests of the parties attending the Hague conference yielded a lowest-common-denominator treaty (League of Nations, 1912). Governments agreed to control the trade in raw opium, but couched their commitment in vague language that required little of states that did not wish to impose substantive regulation. The document called for "gradual" elimination of prepared opium (the type suitable for smoking) but did not stipulate a deadline to accomplish that goal. States consented to eliminate opium exports to countries that prohibited its import but exempted Chinese treaty ports through which the majority of illicit trafficking occurred. Jurisdictions in which opium growing contributed significantly to the economy refused to impose curbs on cultivation. Regulation of pharmaceutical drugs proved equally contentious. German representatives insisted on diluting control provisions for heroin and morphine, as well as excluding codeine entirely. The draft agreement's provisions applied to drugs derived from coca as well, which expanded the number of constituencies impacted by the treaty. After the delegates completed their negotiations, the issue of universal application arose. Several representatives stated that, in order to create an effective and even-handed control regime, many states not attending the conference must also adhere to the treaty. They refused to sign unless the document stated that an additional 34 countries not represented at the Hague negotiations must also ratify before the treaty could enter into force. ${ }^{5}$

The same countries that sent representatives to the 1909 Shanghai meeting, except Austria-Hungary. Argentina, Austria-Hungary, Belgium, Bolivia, Brazil, Bulgaria, Cambodia, Chile, Costa Rica, Cuba, Denmark, Dominican Republic, Ecuador, Greece, Guatemala, Haiti, Honduras, Luxembourg, Mexico, Montenegro, Nicaragua, Norway, Panama, Paraguay, Peru, Romania, El Salvador, Serbia, Spain, Sweden, Switzerland, Turkey, Uruguay, Venezuela. 
Contemporaries judged as remote the likelihood of universal adherence; substantive regulation of the international flow of drugs appeared improbable in the foreseeable future. Altogether, the 1912 Hague treaty represented more a statement of progressive principles than a definitive plan of action. Nevertheless, the outcome reinforced the trajectory initiated in the previous decade. Rather than expressing discouragement, control advocates redoubled their efforts to advance the cause.

Indeed, government at all levels increasingly moved to regulate the medicinal sector. Local, provincial, and national authorities passed laws that ensured drug purity and accurate labelling, delineated the responsibilities of doctors and pharmacists, tracked the activity of distributors, and criminalized non-medical use. As the number, type, and availability of drugs steadily increased after the turn of the twentieth century, societies increasingly concluded that the problems associated with an unregulated drug marketplace necessitated control measures. ${ }^{6}$

The outbreak of the Great War in 1914 also propelled governments toward enhanced drug regulation. Many belligerent states imposed some type of limitation on consumption of psychoactives - including alcohol - to enhance sobriety among the populace in general and the soldiery in particular. Concerns grew about illicit trafficking, addiction, and contraband trading of essential medicinal drugs that might abet the enemy. The UK devised a bookkeeping system to track drug imports and exports that other nations soon emulated. Moreover, supplies

6 In addition to the voluminous literature on the Harrison Narcotics Tax Act (1914) and other US national and subnational legislation, for other states see: Manderson, D. (1993) From Mr. Sin to Mr. Big: A History of Australian Drug Laws. Melbourne: Oxford University Press, ch. 1-5; Giffen, P.J., Endicott, S. and Lambert, S. (1991) Panic and Indifference: The Politics of Canada's Drug Laws. Ottawa: Canadian Centre on Drug Abuse, ch. 1-11; for Belgium (p. 60), Germany (pp. 100-104), Portugal (pp. 164-166), Spain (pp. 182-183), Sweden (pp. 195-197), Switzerland (p. 206), and the UK (pp. 217-218) see Colson, R. and Bergeron, H. (2017) European Drug Policies: The Ways of Reform. New York: Routledge; Houborg, E. (2014) 'Construction and Handling of Drug Problems in Denmark from the 1870s to the 1980s', Nordic Studies on Alcohol and Drugs, 31(5-6), pp. 527-550; Padwa, H. (2012) Social Poison: The Culture and Politics of Opiate Control in Britain and France, 1821-1926. Baltimore: Johns Hopkins University Press; Hoffmann, A. (2012) Drogenkonsum und -kontrolle: Zur Etablierung eines sozialen Problems im ersten Drittel des 20. Jahrhunderts. Wiesbaden:VS Verlag fuer Socialwissenschaften; Kingsberg, M. (2014) Moral Nation: Modern Japan and Narcotics in Global History. Berkeley: University of California Press, ch. 1; for Norway (p. 187), Switzerland (p. 136), and the UK (pp. 99-101) see Wardell, W.M. (ed). (1978) Controlling the Therapeutic Use of Drugs: An International Comparison. Washington, DC: American Enterprise Institute; Boullosa, C. and Wallace, M. (2015) A Narco History: How the United States and Mexico Jointly Created the "Mexican Drug War'. New York and London: OR Books, ch. 1; Vasilyev, P. (2012) 'Medical Science, the State, and the Construction of the Juvenile Drug Addict in Early Soviet Russia', Social Justice, 38(4), pp. 31-52; Conroy, M.S. The Soviet Pharmaceutical Business During its First Two Decades (1917-1937). New York: Peter Lang, (2006), ch. 1 does not provide exact dates of foundational legislation, but illustrates that the Czarist government instituted thoroughgoing measures to regulate the pharmaceutical manufacturers and drug retailers; Parissinen, T. (1983) Secret Passions, Secret Remedies: Narcotic Drugs in British Society, 1820-1930. Philadelphia: Institute for the Study of Human Issues; Berridge, V. (1987) Opium and the People: Opiate Use in Nineteenth-Century England. New Haven, CT: Yale University Press, ch. 8-19; Compilation of laws; digest of state, federal, dominion and provincial Canada and Latin American laws relating to foods, drugs, pharmacy, poisons, narcotics, insecticides, fungicides, caustic acids, weights and measures, sample distribution, stock medicines, alcohol, prohibition, advertising, trade marks, trade practices (including enactments of the 1927 legislatures) (1927) Washington: Standard Remedies Publishing Co., 11th ed. My thanks to research assistant Michael Yuan Tian for his substantial contribution to compiling this bibliography. 
burgeoned: the Entente blockade against the Central Powers interdicted the trade in pharmaceuticals, and several states independently developed substantial new drug development and manufacturing capabilities. By late 1918 the global capacity to produce medically valuable but addicting substances had significantly increased. After the Armistice, a growing, sophisticated transnational pharmaceutical industry sought markets for its products. Taken together, those phenomena reinforced governments' propensity to forge a functional international drug control regime.

Two important developments in the immediate post-war period launched global drug control policy permanently on to the world stage. The victorious powers included in the peace treaties a requirement that all signatories must ratify the 1912 Hague Convention. That provision resolved the universality issue because most of the recalcitrant states, including Germany, Turkey, and Serbia/Yugoslavia were forced to join the system. ${ }^{7}$ The remaining laggard governments soon adhered. In 1921 the treaty entered fully into force. The post-war negotiations also created the League of Nations and charged the fledgling organization with administering the 1912 Hague agreement. The League formed a body of political representatives to address the issue (popularly known as the Opium Advisory Committee), included the topic on the agenda of the League Health Committee (forerunner of today's World Health Organization), and provided a secretariat to support the drug control function (under the aegis of the League's Opium and Social Questions Section). With an issue-specific structure divided into political and medical spheres of competence, supported by a supra-national bureaucracy dedicated to the issue (rather than to any government), future debates about the drug question could not escape reference to those international entities.

The League organs charged with addressing the drug question placed early priority on determining the extent of the problem, which resulted in an emphasis on quantitative supply control. League officials circulated questionnaires to governments, assaying essential statistical information such as imports, exports, transhipments, amounts consumed, and stocks held in reserve. Many states did not collect such information systematically, and thus the early years of League operations focused largely on securing enough data of sufficient uniformity to make judgements and comparisons. They came to a startling assessment: the worldwide supply of opiates far exceeded even the most liberal calculation of legitimate medical-scientific requirements. Moreover, League officials could not agree on what level of consumption constituted "legitimate" need. Physicians on the Health Committee argued for a lower figure because they feared iatrogenic addiction. Members of the Opium Advisory Committee represented national governments, which incorporated the interests of pharmaceutical companies; they advocated much higher amounts should be allowed for licit purposes. Debates between representatives of those opposing constituencies soon dominated the discussion, which caused international drug control negotiations to focus almost exclusively on the supply side of the issue. Quantitative considerations also quickly dominated the deliberations because attempts to examine the drug

See Versailles treaty, Article 295, https://www.loc.gov/law/help/us-treaties/bevans/m-ust000002 0043.pdf (accessed 12 April 2019); St. Germain treaty, Article 247, http://www.austlii.edu.au/au other/dfat/treaties/1920/3.html (accessed 12 April 2019); Trianon treaty, Article 230, https://wwi.lib byu.edu/index.php/Part IX - X (accessed 12 April 2019): Neuilly Treaty. Article 174, https://wwi.lib byu.edu/index.php/Section_II - PART VII, REPARATION. ARTICLES 121 - 176 (accessed 12 April 2019): Sevres treaty, Article 280, https://wwi.lib.byu.edu/index.php/Section_II, Annex II, and Articles_261__ 433 (accessed 12 April 2019). 
question from the demand side foundered amidst myriad complexities. League health officials investigated the causes of addiction but found it impossible to clarify a serviceable definition of the phenomenon; the factors that contributed to any particular individual becoming addicted appeared too variable to generalize. Lacking a plausible formula to assign responsibility and therefore recommend ameliorative action, physicians' efforts to solve the etiological puzzle fizzled in favour of the more concrete option: counting and then reducing stocks as much as possible.

All that activity, however, operated within an essentially voluntary regime. Adherence to the 1912 Hague treaty demanded little of governments. Once the size and scope of global excess production became apparent, control advocates launched a campaign to negotiate a new treaty with substantive, mandatory provisions. In 1923 US officials and their non-governmental allies led the effort. European leaders attempted to conciliate Washington in hopes that concessions on the drug question might foster closer ties to the League. Deliberations throughout 1923-1924, however, indicated that fundamental conflicts of interest remained unresolved. Most parties maintained positions similar to those espoused in 1911-1912. The US government and like-minded constituencies in other countries favoured a stringent control program featuring severe poppy cultivation limitations, elimination of colonial government opium monopolies, and a narrow definition of legitimate medical use. States that featured pharmaceutical manufacturing capabilities or a significant opium agricultural sector prevaricated. As the parties entered formal negotiations in November 1924 at Geneva, no one could predict whether the nascent global drug control regime would advance, regress, or collapse.

\section{5-1933: RULEMAKING AND INSTITUTION BUILDING}

The 1924-1925 Geneva meeting proved even more contentious than previous negotiations, exemplifying the continued deep divisions about the appropriate scope, scale, and purpose of international drug regulation. Governments with colonial holdings in Asia could not agree on any additional substantive measures to curb opium smoking or reduce opium trading within the region, despite the increasing opprobrium attached to those activities. Western powers contended no improvements were possible until China limited its domestic production. Chinese officials claimed the extraterritorial prerogatives exerted by foreign states fatally undermined all control efforts. The leaders of the US delegation demanded elimination of opium smoking within a decade and firm provisions to restrict opium and coca production to medical and scientific needs. Representatives from other countries expressed surprise at this position because US officials who participated in forging the draft treaty had not pressed those issues. Most considered the US demarche outside the competence of the conference to consider; they had no instructions about how to respond. To avoid a collapse of the negotiations, conference leaders suspended the proceedings in mid-December so delegates could consult with their governments. Positions changed little during the interim. Soon after the conference reconvened in late January 1925 the US and Chinese delegations withdrew. The US never ratified the subsequent treaty, yielding a strikingly anomalous result: the leading state advocating global drug control failed to adhere to one of the foundational agreements intended to promote that goal.

Although overshadowed in the press by those controversies, the remaining conferees agreed upon a series of interlocking provisions that produced a significant advance over the equivocal language of the 1912 Hague agreement (League of Nations, 1925). For the substances 
listed in the treaty, the International Opium Convention of 1925 required governments to submit annual statistics enumerating agricultural production, pharmaceutical manufactures, imports, exports, re-exports, non-military consumption, stocks available for public use, and non-binding estimates of substances required for the subsequent year. The agreement also created a system of import certifications and export authorizations to expose any diversion of drugs from licit channels, facilitated states' capacity to enact enhanced national control measures, and delineated procedures to add new drugs to the list of controlled substances. Notably, states representing pharmaceutical manufacturing interests acquiesced to revealing some proprietary commercial information, valuable information to a key constituency. An amendable, delineated list of controlled substances, statistical reporting, and estimating future needs remain mainstays of the international regime today.

The 1925 Convention also created a semi-judicial body called the "Permanent Central Opium Board" to scrutinize the licit trade. The treaty empowered the Board to examine the statistics and estimates submitted by governments, to make inquiries into any anomalies discovered, to publish reports on a regular basis, and to recommend an embargo restricting licit drug exports to/imports from any country found to violate their obligations. With a somewhat altered remit, the International Narcotics Control Board carries on similar functions today.

The more stringent provisions of the 1925 International Opium Convention nevertheless fell short of a robust control system. Governments eschewed truly substantive drug control in favour of higher-priority interests. Domestic constituencies including pharmaceutical companies, opium and coca growers, medical professionals, trading firms, and military authorities lobbied for provisions favourable to their special concerns; in the aggregate the exemptions they secured reduced the stringency of the treaty. Moreover, states jealously guarded their sovereign prerogatives in the anarchic international arena. A variety of concepts and proposals rejected by the delegates illustrates the factors that limited the reach of control. Governments representing areas in which opium smoking remained a significant activity refrained from committing to a date to end the practice. Pharmaceutical firms lobbied successfully against regulating many manufactured substances. States housing significant pharmaceutical companies inserted language enabling them to revise future estimates-of-need to leverage opportunities for acquiring raw materials under favourable market conditions. Physicians objected to any overly invasive measures to restrict their prescribing prerogatives, as did pharmacists with regard to their dispensing privileges. Governments declined to submit binding estimates of future requirements or reveal the extent of stocks reserved for military needs. Delegates also defeated proposals intended to create a truly powerful Permanent Central Opium Board. They refused the Board authority to determine the amount of drugs to be manufactured each year based on the estimates submitted. States denied the Board compulsory embargo powers. Governments did not sanction a fully independent Board of disinterested subject-matter experts; they instead engineered a de facto arrangement that ensured countries engaged in major imperial opium cultivation and/or featuring pharmaceutical manufacturing interests enjoyed essentially permanent representation among the Board's members. Finally, governments rejected creation of a fully independent bureaucracy to execute Board functions. Instead they tied the Board's administrative organs to the existing League of Nations secretariat, over which member states exerted more influence.

The 1925 International Opium Convention quickly became a major success. It gained adherents rapidly, entering in to force in 1928. States submitted statistics, the Permanent Central Opium Board reviewed them, and a growing sense of commonly held expectations suffused 
international drug policy exchanges. Despite Washington's refusal to ratify, the US nevertheless participated by adhering to most of the treaty's provisions, sending official representatives to Opium Advisory Committee meetings, and ensuring an American always occupied a seat on the Permanent Central Opium Board.

With the successful launch of the 1925 treaty, issues surrounding 'manufactured drugs' remained the major untreated aspect of the international trade in addicting substances. By the late 1920s, although some physicians still prescribed heroin for legitimate medical purposes, morphine comprised the principal medicament for many maladies. However, addiction-related problems associated with morphine had become sufficiently apparent that pharmaceutical firms had already begun to develop alternative opium-based analgesics they hoped would prove less habit forming. Codeine emerged as the most notable of these early derivative products. It did not dull severe pain as well as morphine, but provided a viable alternative for less serious conditions and featured less problematic addictive properties.

Because the emerging control system focused on supply control, another key issue revolved around the central dilemma of the regulatory impulse: the price point problem. Humans require medicines, but if supplies become too scarce the cost rises to levels that few can afford. In order to keep prices reasonable, the key ingredients (raw opium, coca leaves, etc.), as well as the pharmaceutical substances manufactured from them (morphine, codeine, cocaine, etc.) must be available in sufficient abundance to sustain a competitive market. That overage of supply, however, creates opportunities for leakage into illicit channels.

In the later 1920s, drug negotiators set about addressing the price-oversupply nexus, as well as the advent of new substances featuring differing addiction potential. Preliminary negotiations again exposed major disagreements about the nature of the problem. The principal UK drug diplomat of the era championed a quota scheme. He encouraged pharmaceutical companies to voluntarily divvy up the licit pie amongst themselves in such a way that all received a suitable slice. This proposal proved unworkable because manufacturers could not agree on which firms should be included or what share of the market each merited. Negotiators' positions also varied about the appropriate level of regulation to apply to less-addicting medicines.

Drug diplomats convened at Geneva in 1931 to work out a compromise agreement intended to secure wide adherence. Popularly referred to as the "1931 Limitation Convention" (League of Nations, 1931), the document generated important new provisions that both cemented the international control regime and illustrated its limits. The treaty required governments to submit estimates of the subsequent year's manufacturing output, but those estimates could be revised without penalty in order to take advantage of opportunities to purchase raw materials cheaply or if demand unexpectedly increased. Manufacturing firms did not have to indicate in advance from what source they intended to acquire their supplies, which enabled cultivators to continue legitimately increasing poppy acreage well in excess of that necessary for licit needs. The treaty created a new entity, the Drug Supervisory Body, to receive and examine estimates of manufactured drugs. Moreover, the conference delegates empowered the Body with a unique attribute: it could create estimates for states not party to the treaty. Like the Permanent Central Opium Board, however, the Drug Supervisory Body held no enforcement authority - it could only publicize infractions. The treaty also introduced a key innovation into the international system by instituting differentiated "schedules of control" that imposed graduated levels of restriction based on the perceived addictive potential of each substance: tighter regulation of more addicting drugs and fewer controls over less habituating substances. German firms dominated codeine manufacture, and they insisted on this provision in order 
to support the agreement. The Convention also required signatories to create a "special administration" to ensure domestic implementation of the treaty's provisions, a clear sign of commitment on the part of national governments to incorporate the drug issue into their permanent bureaucratic and functional structures. The Limitation Convention also gained wide acceptance, entering into force only 21 months after the negotiations concluded.

\section{THE TENETS AND EFFECTS OF THE SYSTEM}

In combination, the 1925 and 1931 treaties delineated the basic structure of the international drug control regime that remains intact today. When the Limitation Convention went into effect in 1933 the system featured: (a) clear delineation between the licit trade and illicit trafficking; (b) a global body of political representatives charged with addressing the issue (the League of Nations Opium Advisory, now the United Nations Commission on Narcotic Drugs); (c) an independent adjudicatory body (the Permanent Central Opium Board, now the International Narcotics Control Board); (d) an international medical advisory body (the League of Nations Health Committee, now the World Health Organization); (e) schedules of control featuring differing levels of regulation; (f) statistical reporting about imports, exports, production, manufacture, distribution, retailing, and estimates-of-need; (g) secretariats possessing the professional and technical expertise necessary to support international agency functions; (h) a requirement that all signatories enact laws aligned with the strictures of the international treaties; and (i) a requirement that all signatories create a national agency to enforce a constellation of rules that applied worldwide. The essential operating principles that constitute the global system include the following.

\section{States Play the Preeminent Role in Defining and Implementing the System}

Governments pursue national interest in the international drug arena, as they do in all realms of endeavour. Officials at the national level charged with interpreting and enforcing the rules determine the extent to which they will accommodate the desires of multiple domestic constituencies, including physicians, pharmacists, public health advocates, patients, treatment specialists, pharmaceutical manufacturers, ministries of trade, religious organizations, military authorities, police, and even intelligence agencies. The regime is designed to help "drug abusers" only insofar as that goal is achievable given the many other interests at stake. Of the three principal international agencies, the most influential is the United Nations Commission on Narcotic Drugs, which is comprised of government representatives who promote their nation's interests. Although members of the International Narcotics Control Board are selected according to professional criteria and are not supposed to represent their parent states, an individual from the US and one from the UK have held a seat on the Board since its inception in 1928. Several other key state-actors in the international drug control system, including Germany, France, and India, have enjoyed near-permanent membership. The World Health Organization, in particular its Expert Committee on Drug Dependence, also plays an important role in the regime, but even that medically oriented body cannot fulfil its responsibilities absent the cooperation of nation-states. 


\section{The Drug Treaties Represent a General Agreement among Governments and Other Actors about What Constitutes Appropriate Behaviour in this Issue-Area}

Although not without many disputes, a basic consensus exists about the legitimacy of the drug control rules, practices, and oversight mechanisms. The system delineates what constitutes licit and illicit activity. Even states that do not adhere to one or more of the extant treaties nevertheless find it necessary to respond when called upon to explain activities that take place within their borders. Very few governments opt to defy the system - at least openly-because of the high political, economic, and reputational costs attached to being perceived as a bad actor. Important non-state constituencies, especially drug manufacturers, also wish to present themselves as operating on the licit side of the ledger; they coined the term " "ethical' pharmaceutical company" in the 1930s as a way to distinguish themselves from shady operators who skirted the line through such practices as producing a small amount of product for the licit market while clandestinely selling large amounts to traffickers. The international organizations associated with the drug control regime reinforce the system's norms by utilizing publicity to excoriate offenders and by offering various types of support to ensure conformity with the rules.

\section{The Regime Emphasizes Supply Control}

Despite several attempts, the system's framers have never found a way to promote practical measures designed to significantly reduce demand. Treaty provisions requiring addiction treatment or true prevention (i.e. stipulations likely to persuade individuals to refrain from engaging in problematic drug use in the first instance) have repeatedly foundered because of etiological incoherence. The tangle of factors that causes a particular person to misuse psychoactive substances, and even forging an agreed-upon definition of "abuse," defy categorization.

\section{That Supply-control Emphasis, However, is of an Indirect Nature because the System Favours Relatively Low Prices and Sufficient Abundance of Licit Substances}

During the negotiations preliminary to the 1931 treaty governments considered, but ultimately rejected, proposals by strict limitation advocates to institute direct control over manufacture and commerce. Those measures would have restricted in advance how much of any particular drug could be cultivated, produced, and/or sold in a given year. States feared that imposing such a greater degree of control might result in shortages, cause high prices that would reduce affordability for licit uses, and create disincentives for profit-seeking companies to engage in the business. The only way to ensure widely affordable licit medicines is to allow excess supplies that suppress prices. Inevitably, some percentage of those extra raw materials or manufactured drugs leak into the illicit traffic. The system, therefore, is intended to reduce to a minimum the amount of crossover to the illegal trade.

The regime's design and operation evince several key dynamics that infuse the system, including the following. 


\section{The regime incentivizes licit actors to seek comparative international regulatory advantage, which entails important consequences}

After the 1931 treaty enshrined schedules as an essential control element, pharmaceutical companies funded increasingly sophisticated research-and-development programs. The immediate goal is to concoct medicines that are determined to have less addictive propensity than those produced by competing firms. If a particular company's drug is placed in a less restrictive control schedule, it gains a significant market advantage over competing products because it is easier for doctors to prescribe and patients to procure. Moreover, pharmacologists have long sought to discover the "regulatory holy grail" - a non-addicting analgesic. If it were possible to develop a drug that featured the pain-killing attributes of morphine without causing habituation, that substance might escape the control regime's strictures altogether. The ensuing profits would be enormous. Instead of such panaceas, this dynamic has generated the repeated introduction of new substances only slightly different chemically from their predecessors, accompanied by claims that "this one really is less addicting." Repeatedly, however, experience demonstrated that most such innovations still fostered habituation. Doctors want to offer pain relief, and patients want analgesia; both audiences routinely exhibit credulousness when encountering enticing assertions from for-profit corporations that have invested significant funds into developing and marketing substances designed to leverage control schedules.

On a national level, for example, in the 1950s the government of India adopted a policy designed to distinguish the newly independent state from its competitors in order to foster a profitable industry. Though pharmaceutical manufacturers preferred higher-alkaloid Iranian or Turkish opium, both those countries suffered opprobrium because of poor compliance with the international control regime. New Delhi instituted strict accounting measures over domestic opium production through every stage of cultivation and processing. The government marketed the product as an exemplar of regulatory control, claiming that nothing escaped into the illicit traffic. Despite a comparatively inferior product, because it adhered to the international rules India benefitted from lucrative foreign trade as a primary supplier of licit opium to the world's ethical manufacturers.

\section{The system employs differing standards for various classes of psychoactive substances}

The control regime focuses on what might be called the "traditional drugs of abuse": narcotics (i.e. substances derived from opium or its synthetic equivalents), coca/cocaine, and cannabis. The Conventions treat those drugs as essentially "guilty until proven innocent"-they are considered addictive and therefore subject to control unless proven otherwise. Even by the time the 1931 Manufacturing Convention entered into force, however, new classes of drugs not covered by the treaties had already emerged. Amphetamines, and later barbiturates increasingly permeated industrialized western societies, but the international control regime did not regulate those substances until the 1970s. This bifurcation occurred for several reasons. Conceptions about what constituted "addiction" originally focused on symptoms displayed by those habituated to opiates. When first introduced in the mid-1880s, for example, cocaine was not considered addicting because the drug did not produce the same effects as narcotics. Each successive new class of psychoactive drugs also was presumed non-addicting at first, in part because they emanated from western scientific-medical culture and did not carry the stigma of "old" pre-modern drugs. Moreover, the user base for the new pharmaceuticals consisted almost entirely of mainstream members of western societies, whereas users of opiates, coca, and cannabis were often associated with ethnic minorities or other out-groups. Eventually, however, 
most of the newer psychoactives demonstrated habituating characteristics. Pharmaceutical companies lobbied for decades to exempt their newer drug lines, eventually referred to in the aggregate as "psychotropics," from international control. When finally forced to acquiesce to international regulation in 1971, they successfully advocated for a regime that assumed psychotropics should be considered "innocent until proven guilty" by exempting those substances from several of the key control and reporting provisions long applied to the "traditional drugs of abuse" (McAllister, 2000, pp. 218-234). Finally, governments at no time made serious efforts to include alcohol or tobacco in the international drug control regime. Fully incorporated into mainstream western societies, those substances received a pass, at least until relatively recent efforts to curb tobacco use as exemplified by the World Health Organization Framework Convention on Tobacco Control (World Health Organization, 2003).

\section{Illicit trafficking is an inevitable concomitant of control}

Any regulatory regime creates opportunities for profit-seeking actors willing to run the risks attendant to trading in contraband items. As the international drug control system came on line in the first third of the twentieth century, smugglers and law enforcement agencies engaged in increasingly sophisticated measures to gain advantage. Less efficient, less ruthless traffickers gave way to more organized and violent operators. The authorities responded in kind. A type of "arms race" phenomenon occurred in which both sides vied to acquire better technology, weapons, information networks, and data about their opponents. This "drug trafficking industrial complex," necessarily featuring a perilous dance between licit and illicit partners, remains a permanent feature of the modern world.

\section{3-1939: MIXED RESULTS IMPLEMENTING THE REGIME}

During the mid-late 1930s, drug control advocates experienced their greatest success in the realm of regularizing the licit drug trade. Governments generally submitted accurate estimates-of-need, as well as statistical returns of manufacture, imports, exports, consumption, and stocks on hand. The international organizations created by the 1925 and 1931 treaties monitored the trade and lodged demarches in problematic cases. Legitimate pharmaceutical firms conformed to the rules and participated in the system because doing so benefitted the bottom line. Diversions from legal supply channels declined to negligible levels, and remain so today. The trustworthiness and efficacy of licit medical narcotic substances comprises a significant achievement that benefits patients worldwide.

The regime foundered, however, in addressing the constellation of challenges on the illicit side of the ledger. Unauthorized narcotics manufacture by shady operators supported a global traffic in heroin, morphine, cocaine, and other controlled substances. Some governments proved unable or unwilling to curb offending firms within their territories, despite hectoring from the international control agencies. Moreover, excess agricultural opium production increased, owing in large measure to instability in East Asia. Japanese occupation of increasing swathes of Chinese territory caused all sides to resort to drug trafficking to support their military campaigns. Public censure by governments and international regulatory organs could not fundamentally alter the geopolitical dynamics that dominated the conundrum in the Far East. Finally, the continued existence of colonial opium monopolies across much of Asia and the East Indies islands fostered multiple opportunities for illicit cultivation, manufacture, 
and sales. The British, Dutch, French, and Portuguese governments refused to change their policies, in part because the revenues supported imperial administration, and also because they feared suppressing the monopolies would lead to a significant increase in trafficking. Organized crime syndicates arose to take advantage of the many entrepreneurial opportunities presented by these circumstances. In response, some control advocates promoted a global anti-trafficking treaty that obligated states to adopt uniform criminal penalties and enhanced governments' extradition authority. The resultant agreement, however, gained few adherents owing to differences in legal systems that could not be surmounted and a lack of support from many key governments. The treaty entered into force in October 1939 between a small number of adherents, but the advent of the Second World War rendered it moribund (League of Nations, 1936; McAllister, 2000, pp. 120-123). Negotiations about limiting agricultural cultivation to the number of hectares necessary for licit medical needs, a practical impossibility, went nowhere. As the world descended toward war, the international drug control regime reached an impasse: no additional progress could be expected absent a significant change in the global environment.

Moreover, in the late 1930s several governments launched initiatives to ensure they possessed sufficient medical supplies in case of war. First World War experience indicated that both military and civilian need for narcotics and other controlled substances would substantially increase, especially if an enemy imposed a surface or submarine blockade that visited privation upon the general population. European states increased manufacturing capacity, invented new methods for morphine extraction, and developed the first synthetic analgesics. The US amassed a massive opium stockpile, and cultivated closely guarded test plots of poppy and coca plants in case foreign supplies became unavailable. Unable to prevent any of those developments, control advocates worried about what effect they might have on the system.

\section{0-1946: SECURING SURVIVAL AND SURPRISING SUCCESSES}

Through the Second World War and its immediate aftermath, the international drug control system not only maintained its efficacy, but achieved notable accomplishments. Control advocates eliminated impediments and leveraged the altered post-war geopolitical landscape to promote their cause. The regime emerged from the war years in a stronger position than a reasonable contemporary observer could have expected.

The US government exerted preponderant influence upon the trajectory of international drug policy during the 1940s. Enjoying physical security, productive capacity, monetary reserves, military strength, diplomatic leverage, and an unprecedented cache of licit medicinal opium, Washington imposed its preferences on other actors. Federal Bureau of Narcotics Commissioner Harry Anslinger, the principal figure in the US drug control bureaucracy, directed a multifaceted effort to promote a more stringent international regime.

Led by Anslinger, Federal officials engineered the transfer of essential Permanent Central Opium Board and Drug Supervisory Body operations from Switzerland to the US. The removal preserved the international control organs' existence - they almost certainly would have collapsed had they remained in Geneva. The Board and Body continued to solicit statistical returns from governments, and with enhanced incentive; Commissioner Anslinger threatened to withhold shipments of medicines from non-compliant states. Statistical information proved valuable for more than drug control purposes. Washington incorporated the data into 
economic warfare calculations that indicated the strengths and weaknesses of enemies, allies, and neutrals.

Anslinger also masterminded a major coup by successfully pressuring the principal colonial powers to renounce their centuries-old opium monopolies. Through a campaign of bureaucratic manipulation and diplomatic bluff, he overturned meticulously negotiated inter-Allied occupation policy, which dictated that all pre-war local laws - including government-run drug sales outlets - should be reinstituted upon liberation. Dependent on the US for material and financial support, the UK, Netherlands, and French governments acquiesced without a fight. At a stroke, the Commissioner expunged one of the longest-standing impediments to substantive global drug regulation.

Moreover, as the Allied powers constructed the United Nations Organization to replace the discredited League of Nations, Anslinger and his supporters manoeuvred to create an international drug control structure more likely to promote stricter regulation. They successfully advocated to eliminate the Opium Advisory Committee in favour of a reconstituted "Commission on Narcotic Drugs" that reported directly to the Economic and Social Council. They hoped that structure would more vigorously prosecute a stringent supply-control agenda (United Nations, 1946). They also ensured that like-minded members of the United Nations Secretariat filled key positions in the new bureaucracy. Washington pressured other governments to fully adhere to the extant treaties and moved quickly to negotiate an international agreement controlling synthetic narcotics (United Nations, 1948; McAllister, 2000, pp. 164-165).

\section{ENDURING CHALLENGES}

Despite ostensibly more favourable conditions by the late 1940 s, the fundamental dynamics created by the international drug regulatory regime remained intact. Licit market forces, the attractions of modern medicine, recalcitrant governments, renegade cultivators, unscrupulous manufacturers, clandestine traders, and consumers (either unrepentant or incapable of stopping) combined to bedevil the efforts of control advocates. As the subsequent chapters of this book suggest, the challenges inherent in the global control impetus that emerged over the first half of the twentieth century render this issue a perennial on the world scene.

\section{REFERENCES}

INCB (1959) The Shanghai Opium Commission. Vienna: International Narcotics Control Board, https://www.unodc.org/unodc/en/data-and-analysis/bulletin/bulletin_1959-01-01_1_page006.htm] (accessed 12 April 2019).

League of Nations (1912) International Opium Convention. The Hague: First International Opium Conference. https://treaties.un.org/pages/ViewDetailsIV.aspx?src=TREATY\&mtdsg_no=VI-2\& chapter $=6 \&$ Temp $=$ mtdsg $4 \&$ clang $=$ en (accessed 12 April 2019).

League of Nations (1925) International Opium Convention. Geneva: League of Nations, https:// treaties.un.org/Pages/ViewDetails.aspx?src=TREATY\&mtdsg_no=VI-6-a\&chapter=6\&clang=_en (accessed 12 April 2019).

League of Nations (1931) Convention for Limiting the Manufacture and Regulating the Distribution of Narcotic Drugs. Geneva: League of Nations, https://treaties.un.org/pages/ViewDetails.aspx?src= TREATY\&mtdsg_no=VI-8-a\&chapter $=6 \&$ clang=_en $($ accessed 12 April 2019). 
League of Nations (1936) Convention of 1936 for the Suppression of the Illicit Traffic in Dangerous Drugs. Geneva: League of Nations, https://treaties.un.org/doc/Treaties/1936/06/19360626\%2006-49 \%20AM/Ch_VI_12 ap.pdf (accessed 12 April 2019).

McAllister, W.B. (2000) Drug Diplomacy in the Twentieth Century World. London \& New York: Routledge.

United Nations (1946) Protocol amending the Agreements, Conventions and Protocols on Narcotic Drugs, concluded at The Hague on 23 January 1912, at Geneva on 11 February 1925 and 19 February 1925, and 13 July 1931, at Bangkok on 27 November 1931 and at Geneva on 26 June 1936. New York: United Nations, https://treaties.un.org/doc/Treaties/1948/02/19480203\%2010-47\%20PM/ Ch_VI_1p.pdt (accessed 12 April 2019).

United Nations (1948) Protocol Bringing under International Control Drugs Outside the Scope of the Convention of 13 July 1931 for Limiting the Manufacture and Regulating the Distribution of Narcotic Drugs, as amended by the Protocol signed at Lake Success. New York, on 11 December 1946. New York: United Nations, https://treaties.un.org/doc/Treaties/1949/12/19491201\%2011-57\%20PM/Ch VI_13p.pdf (accessed 12 April 2019).

World Health Organization (2003) Framework Convention on Tobacco Control. Geneva: World Health Organization, https://apps.who.int/iris/bitstream/handle/10665/42811/9241591013.pdf;jsessionid= 5570B3FB3220D2DEC8177CC7075A2F5A?sequence=1 (accessed 12 April 2019). 